\title{
High-Resolution, Shallow, Seismic Reflection Surveys of the Northwest Reelfoot Rift Boundary Near Marston, Missouri
}

U.S. GEOLOGICAL SURVEY PROFESSIONAL PAPER 1538-P

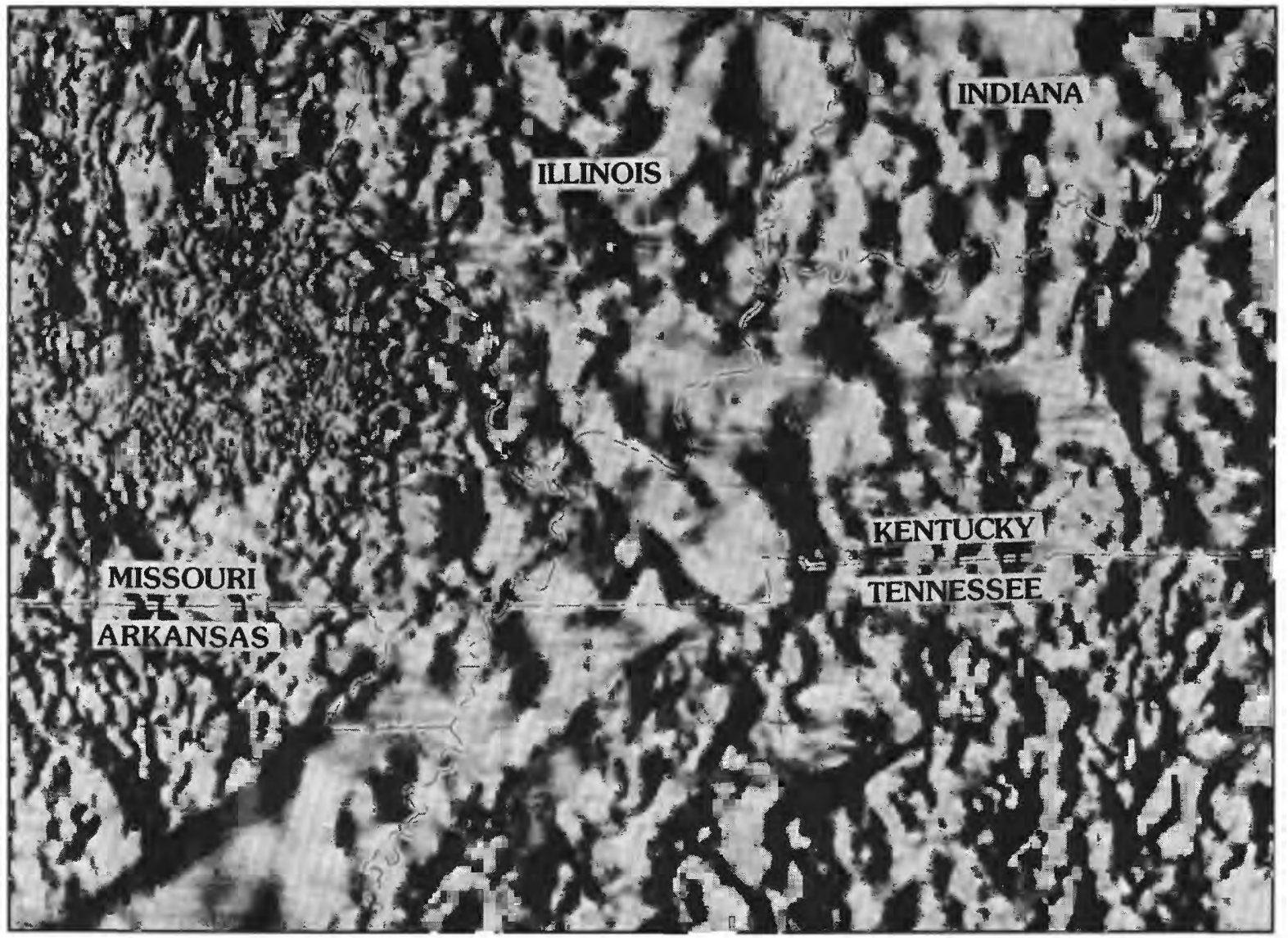


Cover. Gray, shaded-relief map of magnetic anomaly data. Map area includes parts of Missouri, Illinois, Indiana, Kentucky, Tennessee, and Arkansas. Illumination is from the west. Figure is from Geophysical setting of the Reelfoot rift and relations between rift structures and the New Madrid seismic zone, by Thomas G. Hildenbrand and John D. Hendricks (chapter E in this series). 


\section{High-Resolution, Shallow,}

Seismic Reflection Surveys of the Northwest

Reelfoot Rift Boundary Near Marston, Missouri

By Jack K. Odum, Eugene A. Luzietti, William J. Stephenson, Kaye M. Shedlock, and John A. Michael

INVESTIGATIONS OF THE NEW MADRID SEISMIC ZONE

Edited by Kaye M. Shedlock and Arch C. Johnston

U.S. GEOLOGICAL SURVEY PROFESSIONAL PAPER 1538-P

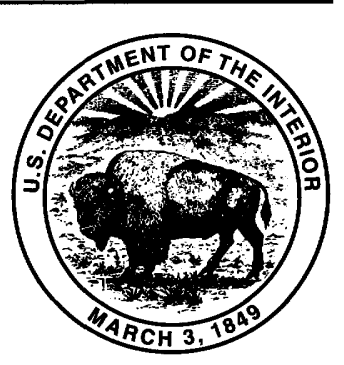

UNITED STATES GOVERNMENT PRINTING OFFICE, WASHINGTON : 1995 


\title{
U.S. DEPARTMENT OF THE INTERIOR BRUCE BABBITT, Secretary
}

\author{
U.S. GEOLOGICAL SURVEY
}

Gordon P. Eaton, Director

For sale by U.S. Geological Survey, Information Services

Box 25286, Federal Center

Denver, CO 80225

Any use of trade, product, or firm names in this publication is for descriptive purposes only and does not imply endorsement by the U.S. Government

\section{Library of Congress Cataloging-in-Publication Data}

High-resolution, shallow, seismic reflection surveys of the northwest Reelfoot rift boundary near Marston, Missouri / by Jack K. Odum ... [et al.].

p. $\quad \mathrm{cm}$. - (U.S. Geological Survey professional paper ; 1538-P) (Investigations of the New Madrid seismic zone ; P)

Includes bibliographical references.

Supt. of Docs. no.: I 19.16:1538P

1. Geology-Missouri-New Madrid Region. 2. Seismic reflection method.

I. Odum, Jack K. II. Series. III. Series: Investigations of the New Madrid seismic

zone ; $\mathrm{P}$

QE535.2.U6I59 1995 vol. P

[QE132.N47]

$551.2^{\prime} 2^{\prime} 09778985 \mathrm{~s}-\mathrm{dc} 20$

[557.78985] 


\section{CONTENTS}

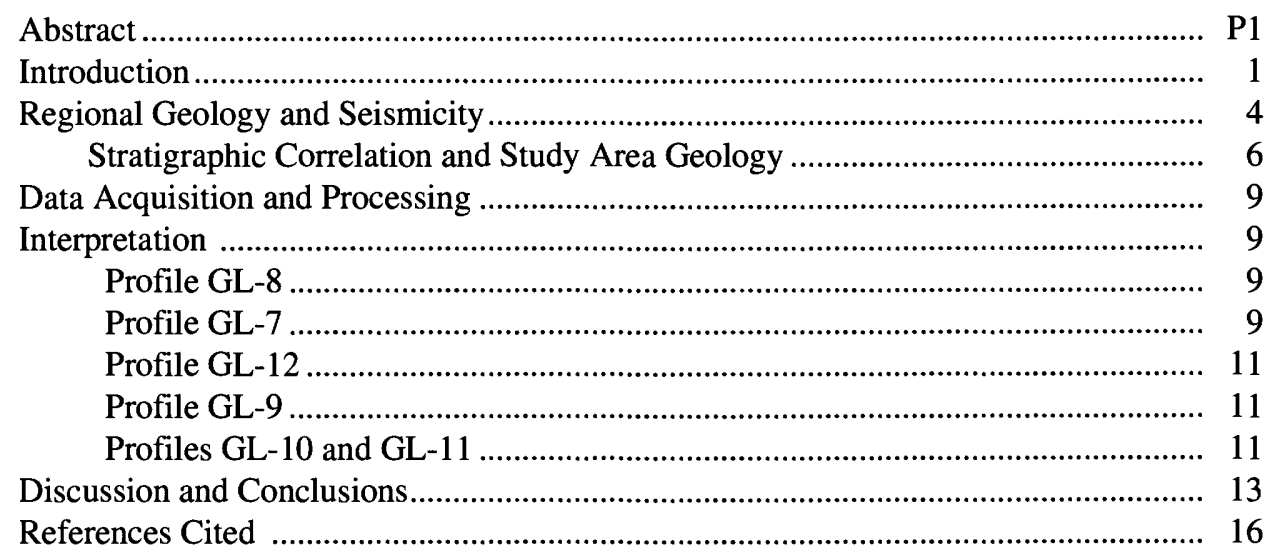

\section{FIGURES}

1. Regional map of the northern Mississippi Embayment

2. Map showing location USGS Vibroseis line S-3, six high-resolution seismic reflection lines, and three drill holes

3. Cross section constructed from interpreted resistivity logs from two geophysically logged drill holes and a lithologic column

4. Migrated seismic reflection profile GL-8 and interpreted line drawing....................................................... 7

5. Migrated seismic reflection profile GL-7 and interpreted line drawing ............................................................... 8

6. Migrated seismic reflection profile GL-12 and interpreted line drawing..................................................... 10

7. Migrated seismic reflection profile GL-9 and interpreted line drawing..................................................... 12

8. Migrated seismic reflection profiles and interpreted line drawing for lines GL-10 and GL-11 ........................... 13

9. Vertical aerial photograph showing spatial location of high-resolution seismic reflection lines and three ages of abandoned meander channels associated with the modern Mississippi River

10. Conceptual map displaying spatial relationship and trend of structural feature interpreted from seismic profiles GL-7, GL-9, and GL-12

\section{TABLES}

1. Data-acquisition parameters 



\title{
HIGH-RESOLUTION, SHALLOW, SEISMIC REFLECTION SURVEYS OF THE NORTHWEST REELFOOT RIFT BOUNDARY NEAR MARSTON, MISSOURI
}

\author{
By Jack K. Odum, ${ }^{1}$ Eugene A. Luzietti, ${ }^{2}$ William J. Stephenson, ${ }^{1}$ \\ Kaye M. Shedlock, ${ }^{1}$ and John A. Michael ${ }^{1}$
}

\begin{abstract}
The 1811-12 New Madrid earthquakes are believed to be among the strongest historical events to have ever occurred in North America; however, little surficial deformation exists to document this sequence of strong ground-shaking events. Approximately $9 \mathrm{~km}$ southwest of New Madrid, Mo., six high-resolution seismic reflection profiles image strata near the presumed epicenter of one of these historical 1811-12 earthquakes. Three of the six profiles image what we interpret to be a master and antithetic fault pair that are traceable for approximately $6 \mathrm{~km}$. Geomorphic evidence suggests that this fault pair may be traced for as much as $15 \mathrm{~km}$. The trend of these faults, which may represent a segment of a wider fault zone, is approximately N. $50^{\circ}-55^{\circ}$ E. - an orientation subparallel to the aeromagnetically defined Reelfoot rift boundary and other regionally identified structural features.

Our interpretation shows deformation in the form of normal and reverse movement across the Paleozoic surface reflector. Displacement on this reflector decreases from a maximum of $30 \mathrm{~m}$ upward through the section. Although noticeable vertical displacement decreases upward through the younger strata, stream-channel entrenchment largely confined within the downwarped area (graben) between a master and antithetic fault pair indicates that at least minor amounts of movement occurred into the middle Eocene. The lack of surface and near-surface deformation, along with subtle changes in reflector characteristics across fault traces, may be indicators that strike-slip fault movement became prevalent during the late Tertiary.
\end{abstract}

${ }^{1}$ U.S. Geological Survey, Mail Stop 966, P.O. Box 25046, Denver Federal Center, Denver, CO 80225.

${ }^{2}$ Chevron USA Production Company, 935 Gravier St., New Orleans, LA 70112 .

\section{INTRODUCTION}

The northern Mississippi Embayment was rocked by hundreds of small earthquakes and three high-magnitude events during the winter of 1811-12. The February 7, 1812, event, with an estimated magnitude of about $\mathbf{M} 8.3$ (Johnston, in press), totally destroyed the town of New Madrid, Mo. Although a large amount of the regional strain energy may have been dissipated by the three large earthquakes (December 16, 1811; January 23 and February 7, 1812), an instrumentally defined pattern of concentrated modern seismic activity currently exists within the northern Mississippi Embayment (fig. 1) (Stauder and others, 1976; Johnston and Nava, 1990; Chiu and others, 1992). This pattern of modern seismicity, the New Madrid seismic zone (NMSZ), geographically encompasses portions of southeast Missouri, northwest Tennessee, and northeast Arkansas and is largely confined within the aeromagnetically and gravity-defined boundaries of the Reelfoot rift graben. It is widely recognized as one of the most seismically active regions east of the Rocky Mountains.

The New Madrid earthquakes, which occurred during the winter of 1811-12, are among the strongest historical events to ever have occurred in a stable continental setting (Johnston and Kanter, 1990), but little surficial deformation exists to document this sequence of strong ground-shaking events. The most common and widespread surficial evidence include sandblows, earthquake-induced landslides along river bluffs, sunken terrain (sloughs), and small (generally less than $10 \mathrm{~m}$ ) upwarps. Thick deposits of unconsolidated Pleistocene and Holocene alluvium, and lateral planation accompanied by cut-and-fill channeling of the ancestral and modern Mississippi and Ohio Rivers, make it difficult to identify evidence of faulting in near-surface strata.

Seismic reflection data has been acquired throughout the Mississippi Embayment to help identify subsurface structures. Vibroseis seismic reflection surveys have been useful in delineating major deformational features (warping and faulting) that have disrupted Paleozoic and 


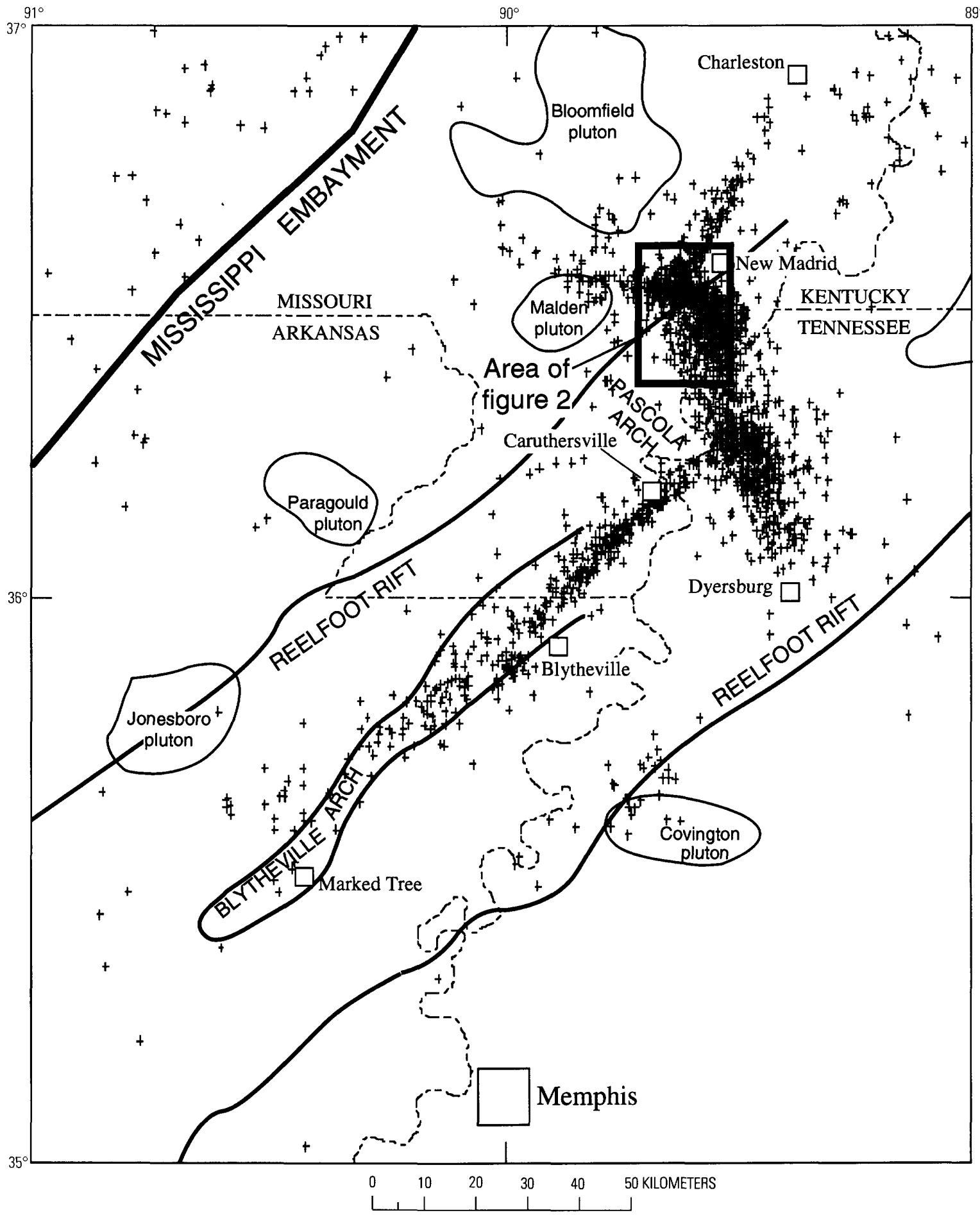

Figure 1. Regional map of the northern Mississippi Embayment showing the location of study area seismic reflection surveys (box) in relation to the Reelfoot rift boundaries and inferred plutons (Hildenbrand and Hendricks, 1995), Blytheville arch (Hamilton and McKeown, 1988), Pascola arch (Grohskopf, 1955), and epicenters (crosses) of earthquakes of $M \geq 1.5$ (Taylor and others, 1991). Figure is modified from Luzietti and others (1992).

Cretaceous strata (Crone and Brockman, 1982; Hamilton and Zoback, 1982; Hamilton and McKeown, 1988; Sexton and others, 1982). However, poorly resolved upper
Tertiary and Quaternary reflectors make it impossible to trace deformation features into the shallow subsurface. During the last decade, more than $100 \mathrm{~km}$ of 


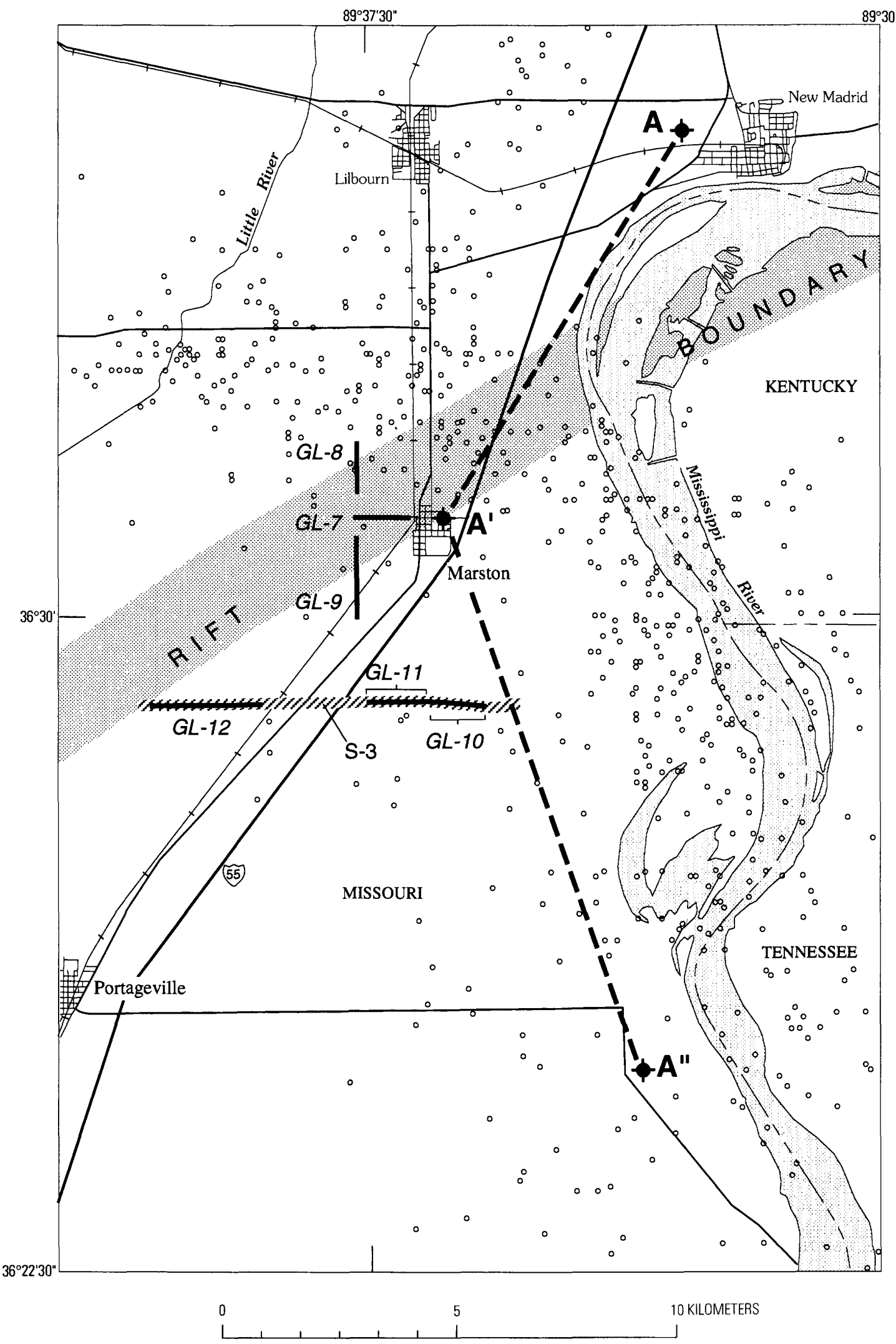

Figure 2. Map showing location of U.S. Geological Survey (USGS) Vibroseis line S-3 (hachured line), six high-resolution Mini-Sosie seismic reflection lines (heavy black lines), and three drill holes (black well symbols) used for stratigraphic correlation. Generalized northwestern edge of rift boundary is surface projection of the steepest gradient in the magnetic field that is used by Hildenbrand and Hendricks (1995) to delineate the rift boundary. Open circles are epicenters of earthquakes with $M \geq 1.5$. Section $A-A^{\prime}-A^{\prime \prime}$, based on drill-hole data, is presented in figure 3 . 
high-resolution reflection data have been acquired throughout the Mississippi Embayment to image Tertiary and younger strata and permit detailed analysis of shallow (less than $1 \mathrm{~km}$ deep) deformation (Shedlock and Harding, 1982; Sexton and Jones, 1986, 1988; Luzietti and Harding, 1991; Luzietti and others, 1992; Schweig and others, 1992; VanArsdale and others, 1992).

This paper presents the interpretation of six Mini-Sosie high-resolution seismic reflection profiles in southeastern Missouri (fig. 2). These profiles are located within a broad zone that coincides with the surface projection of the aeromagnetically and gravity-defined northwestern boundary of the Reelfoot rift graben and are in close proximity to the assumed February 7,1812 , earthquake epicenter.

\section{REGIONAL GEOLOGY AND SEISMICITY}

The Mississippi Embayment extends from the Gulf Coastal Plain northward to approximately the confluence of the Mississippi and Ohio Rivers. Based on aeromagnetic and gravity data collected in 1974, a northeast-trending graben (approximately $300 \mathrm{~km}$ long and $70 \mathrm{~km}$ wide) has been interpreted beneath the northern Mississippi Embayment (Hildenbrand and others, 1977; Kane and others, 1981). The Reelfoot rift graben, a major near-surface structural feature, is part of a larger tectonic structure within the craton: the Reelfoot rift system (Hildenbrand, 1985). Magnetic modeling suggests a depth to magnetic basement of 4-5.5 km within the graben. This represents a variable amount of vertical structural relief (ranging from 1.5 to $2.5 \mathrm{~km}$ ) with respect to the regional magnetic basement (Hildenbrand and Hendricks, 1995). Contouring of the Precambrian surface, using drill-hole and geophysical data, indicates that the graben consists of at least two deep basins (half-grabens) separated by one or more transverse ridge structures (R.L. Dart, oral commun., 1993).

The Reelfoot rift graben is believed to have developed as a result of incipient rifting during latest Proterozoic to Early Cambrian time (Bond and others, 1984; Kolata and Nelson, 1991). By the Late Cambrian, most tectonic activity had ceased and the rift complex was filled with approximately $3 \mathrm{~km}$ of sediment (Kolata and Nelson, 1991). Deposition of shallow-marine carbonate sequences, sandstone, siltstone, and shale continued into the Pennsylvanian (Cushing and others, 1964). Compressive stresses, probably associated with the late Paleozoic Ouachita and Allegheny orogenies, reactivated some Reelfoot rift boundary faults, resulting in both normal and reverse movement (Kolata and Nelson, 1991). These compressive stresses also induced strike-slip, oblique, and reverse fault movement along the axial Reelfoot rift fault zone and possibly caused uplifting of the Pascola arch (Howe and Thompson, 1984; Kolata and Nelson, 1991). Zones of weakness along the rift margins and axial fault zone provided sites for emplacement of felsic and mafic intrusions (Howe and Thompson, 1984; Kolata and Nelson, 1991). Regional uplift lasted into the late Mesozoic, and extensive erosion removed as much as $4,600 \mathrm{~m}$ of Paleozoic strata from the top of the Pascola arch (Marcher and Stearns, 1962). Upper Paleozoic to middle Cretaceous rocks are missing in the northern Mississippi Embayment.

A renewed episode of basin-wide downwarping during the Late Cretaceous initiated a cycle of sedimentation with only two major and a few minor interruptions (Stearns, 1957). Drill-hole and geophysical data have identified mafic to ultramafic plutons along the rift margins and within the graben that are thought to have been emplaced during the late Mesozoic (Hildenbrand and Hendricks, 1995). Following the cessation of a major period of subsidence in middle to late Eocene time, the embayment was uplifted and erosion dominated until the close of the Tertiary (Stearns, 1957). Thin sheets of coarse-grained fluvial and alluvial deposits were laid down during the late Pliocene(?) and early Pleistocene (Potter, 1955; Russell and Parks, 1975). Mid to late Pleistocene glacial-outwash deposits and windblown loess, of variable thickness, mantled surfaces within and adjacent to the Mississippi Embayment. Lateral planation and major channel shifts by the modern Mississippi and Ohio River systems are currently eroding and reworking relict braided streams, glacial-outwash plains, and modern Holocene-age alluvial deposits (Royall and others, 1991; Autin and others, 1991).

Reelfoot rift system structures have undergone several episodes of compression and extension. Currently, and probably beginning as early as the Miocene, the Mississippi Embayment is being compressed by predominantly uniform horizontal stresses (Johnston and Nava, 1990). In the NMSZ, the principal axis of compression is oriented approximately N. $80^{\circ} \mathrm{E}$., whereas the principal axis for the Central United States as a whole is N. $60^{\circ}$ E. (Zoback and Zoback, 1981). Within the Reelfoot rift system, faults with northeast-southwest orientations are believed to respond to the regional stress orientation, with predominantly right-lateral strike slip along with small amounts of normal, oblique, and reverse movement (Russ, 1982; Zoback and Zoback, 1989; Dart and Swolfs, 1991). The New Madrid seismic zone consists of three major trends of seismicity (fig. 1): a major zone extends northeast for $120 \mathrm{~km}$ along the rift axis from near Marked Tree, Ark., to Caruthersville, Mo.; a second northeast-trending zone lies outside of the rift margin along a 40-km-long line from New Madrid to Charleston, Mo. A third zone, oriented north-northwest, connects these two zones. Between October 1989 and January 1992, more than 700 earthquake events were recorded on the PANDA (portable array for numerical data acquisition) network, which is 


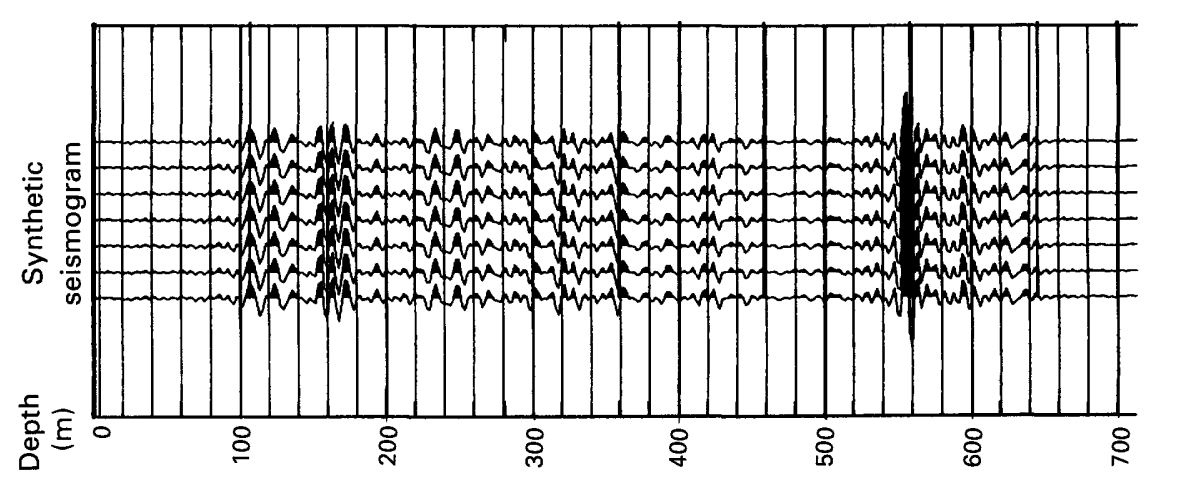

至

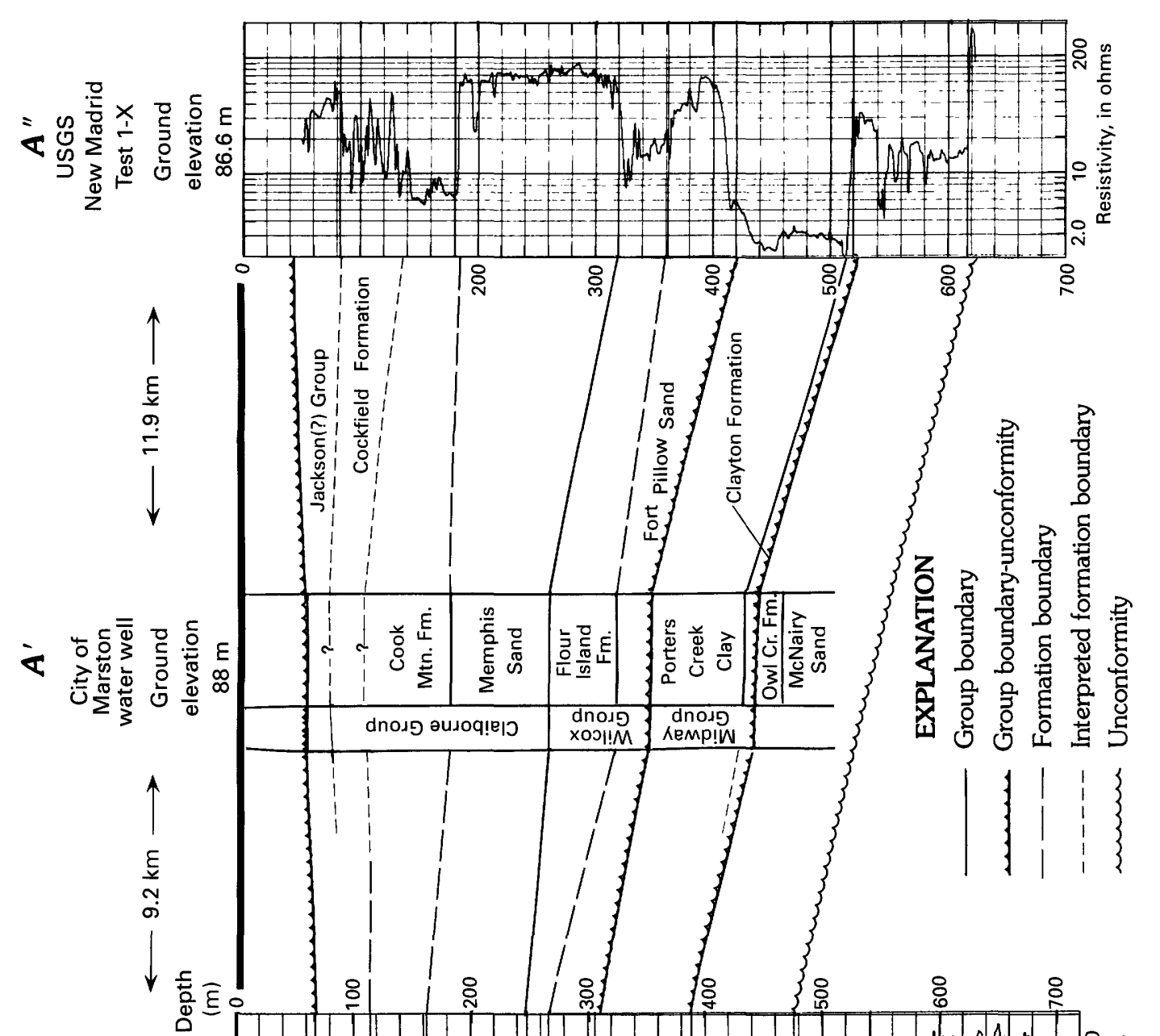

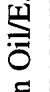

.ำ

욤

总

实

迹事

焉就

总 $\frac{3}{0}$

을

충 흐

氛

究芒

蚊

政

हี

品

음

롱응

.

옹응

实

풍

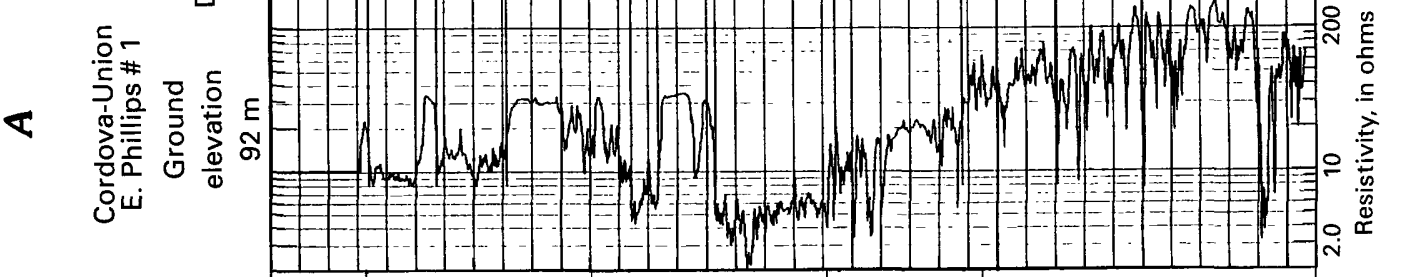

\begin{tabular}{|c|c|c|c|c|}
\hline 'Is!ald & әиәวо & әиәэоәре & $\begin{array}{c}\text { snoəoeled } \\
\text { Jədd }\end{array}$ & \\
\hline סקen & \multicolumn{2}{|c|}{ Ке!ฺнә } & $\begin{array}{l}\text { snoəor } \\
\text {-ełəנ丶万 }\end{array}$ & ue!’!^ордо-ue!ıqщеว \\
\hline \multicolumn{3}{|c|}{ JIOZONヨJ } & -OS JOZ & ગ10ZOت77d \\
\hline
\end{tabular}


deployed within this transverse zone (Chiu and others, 1992). Hypocenters are generally $5-15 \mathrm{~km}$ deep, and the earthquakes have magnitudes ranging from $<0.0$ to 4.6 (Chiu and others, 1992). The pattern and focal mechanism of the hypocenters indicate a variety of faulting styles within the transverse zone including thrust, strike-slip, normal, and reverse (Chiu and others, 1992). The Marston, Mo., study area falls within this transverse zone of seismicity (fig. 2).

\section{STRATIGRAPHIC CORRELATION AND STUDY AREA GEOLOGY}

Two geophysically logged exploratory drill holes and one lithologic log from a water well (fig. 2) provide local subsurface information that can be used to correlate the seismic reflection data with stratigraphic horizons. The two geophysically logged drill holes, the Cordova-Union Oil/E. Phillips No. 1 and the USGS New Madrid Test Well 1-X (Crone, 1981) (A and A", respectively, fig. 2) are $21 \mathrm{~km}$ apart. A stratigraphic cross section (fig. 3), incorporating the resistivity $\log$ interpretations and the lithologic description from the city of Marston water well $\left(A^{\prime}\right)$, shows the regional continuity of formation contacts and thicknesses across the study area. The synthetic seismogram generated from the USGS New Madrid Test Well $1-X$ geophysical logs indicates that the impedance across major unconformities and lithologic contacts is significant enough to produce regionally observable reflectors.

Within the study area, extensive erosion during the late Paleozoic and Mesozoic removed several kilometers of rock from the uplifted Pascola arch, leaving behind a Paleozoic bedrock surface that dips gently southeast toward the embayment axis with a slope of approximately $6.6 \mathrm{~m} / \mathrm{km}$ (Marcher and Stearns, 1962; Boswell and others, 1965). The Upper Cretaceous McNairy Sand, consisting of sand, clay, and marl deposited within a fluvial and rapidly expanding deltaic environment, lies unconformably upon this low-relief Paleozoic surface (Pryor, 1960). The Owl Creek Formation, largely composed of reworked upper McNairy Sand in the northern embayment, represents an episode of subsidence and rapid sea transgression following a period of uplift and tilting (fig. 3) (Pryor, 1960). During the Paleocene, a marine transgression completely covered the embayment, and shallow- to deep-water marine clay and shale were deposited. The thin, calcareous and sandy Clayton Formation unconformably overlies the Upper Cretaceous rocks. The Clayton Formation grades upward into the Porters Creek Clay. Together, these formations make up the Midway Group. In the northern embayment, a sharp unconformity marks the contact between the Midway Group and the overlying Paleocene and lower Eocene Wilcox Group (Fort Pillow Sand and Flour Island Formation). The shallow-water to deltaic Fort Pillow Sand is overlain by nonmarine back-beach and deltaic silt and clay of the Flour Island Formation. The
Table 1. Data-acquisition parameters.

[pt, point; gp, group; config, configuration]

\begin{tabular}{|c|c|}
\hline Parameter & Description \\
\hline \multicolumn{2}{|c|}{ Source type .................... 3 earth compactors } \\
\hline Source array. &. 2-m spacing parallel to profile line \\
\hline Source durati & $. .1,500-2,000$ impulses per shot pt \\
\hline \multicolumn{2}{|c|}{ Source point interval ...... $9.14 \mathrm{~m}(30 \mathrm{ft})$} \\
\hline \multicolumn{2}{|c|}{ Geophone array .............. 1-m point area } \\
\hline \multicolumn{2}{|c|}{ Geophone gp spacing ...... $9.14 \mathrm{~m}(30 \mathrm{ft})$} \\
\hline \multicolumn{2}{|c|}{ Geophone config ............ 24 channel, end-on } \\
\hline \multicolumn{2}{|c|}{ Field filters ...................40-180-Hz band pass, $24 \mathrm{~dB} /$ octave } \\
\hline \multicolumn{2}{|c|}{ Recording system ............ I/O DHR 2400} \\
\hline \multicolumn{2}{|c|}{ Sampling rate................. $1 \mathrm{~ms}$} \\
\hline Trace length. & $. .1,000 \mathrm{~ms}$ \\
\hline
\end{tabular}

Claiborne and Jackson Groups, of Eocene age, unconformably overlie the Wilcox Group. The basal unit of the Claiborne Group, in the upper Mississippi Embayment, is a fluvial, deltaic, and coastal-plain sand, regionally referred to as the Memphis Sand (Grohskopf, 1955). Above this basal sand are interbedded silt, clay, lignite, and lenticular sand, which probably correlate with the Cook Mountain and Cockfield Formations (Grohskopf, 1955). The Jackson Group (not positively identified within the study area), composed of very fine to medium-grained fluvial, deltaic, and coastal-plain sand, was deposited during the last marine transgression in the upper Mississippi Embayment (Mann and Thomas, 1968; Stearns, 1957). The northern embayment underwent regional uplift and erosion throughout the remainder of the Tertiary. The Jackson(?) and Claiborne Groups are unconformably overlain by veneers of late Pliocene and Pleistocene alluvium, colluvium, glacial outwash, and windblown loess (Guccione and others, 1990; Autin and others, 1991).

During the Pleistocene, the Mississippi River flowed west of its present position in the modern western lowlands, and it was the ancestral Ohio River that laterally scoured out a large flood plain across the study area (Stephenson and Crider, 1916; Fisk, 1944; Saucier, 1964). Headward erosion and stream capture by an Ohio River tributary and (or) increased flow resulting from melting ice sheets caused the Mississippi River to gradually abandon its course and join the Ohio River south of New Madrid, Mo. (Stephenson and Crider, 1916; Saucier, 1964). The present river configuration was established approximately 10,000 yr B.P. (Teller, 1990; Royall and others, 1991). During the Holocene, the Mississippi River and its embayment tributaries developed the sedimentary sequences and geomorphic features associated with a large meandering river regime (wide flood plain, point bars, incised and abandoned meander channels, and laterally extensive clay "plugs"). In some places, modern channels have eroded into strata of the Tertiary Claiborne Group; the channels have been abandoned; and they have been filled with extensive, younger flood-plain deposits. 

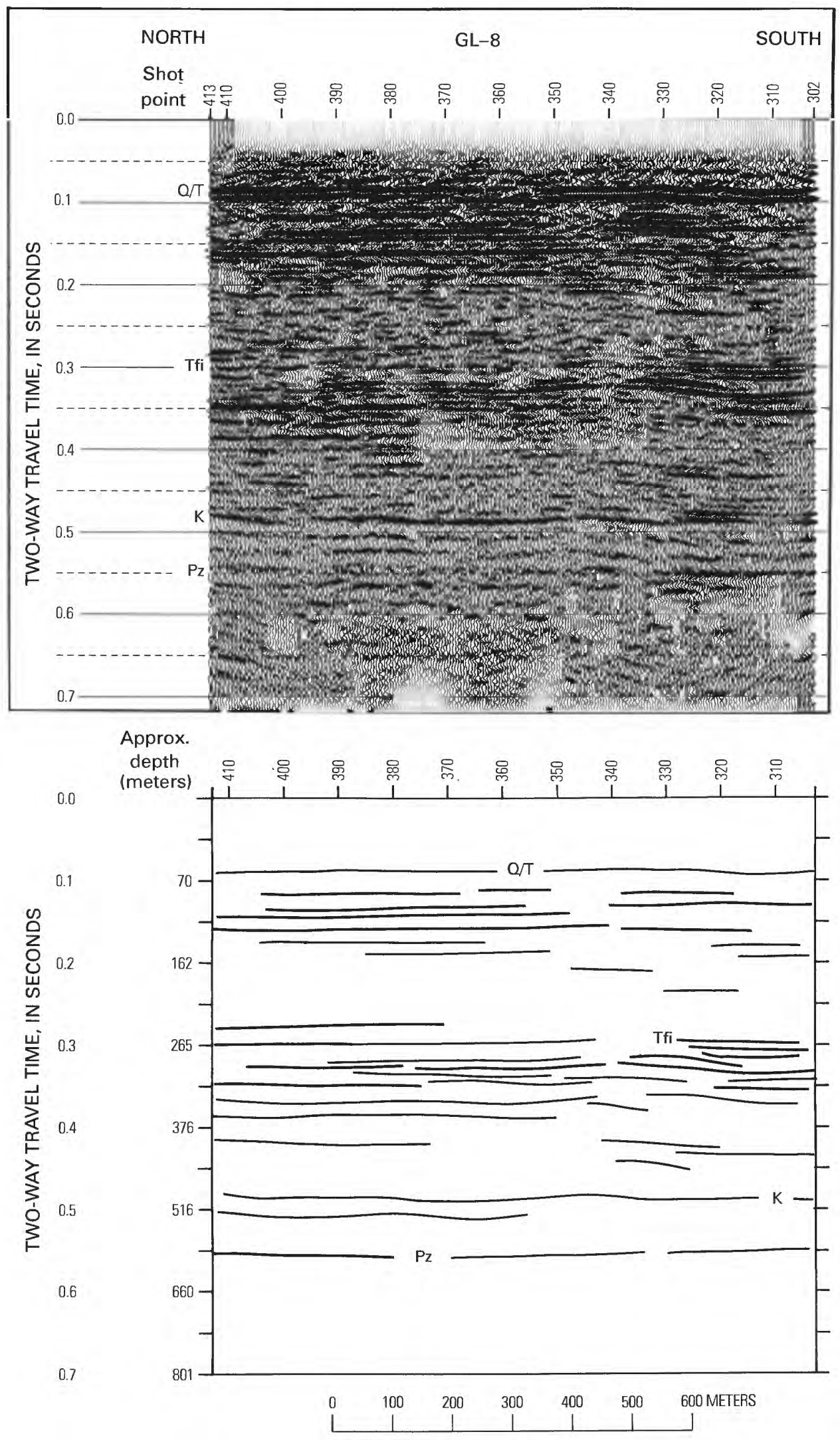

Figure 4. Migrated seismic reflection profile GL-8 and interpreted line drawing. Labeled reflectors: Pz, top of Paleozoic rocks; K, top of Cretaceous rocks; Tfi, top of Paleocene and Eocene Flour Island Formation; Q/T, Quaternary-Tertiary unconformity. 

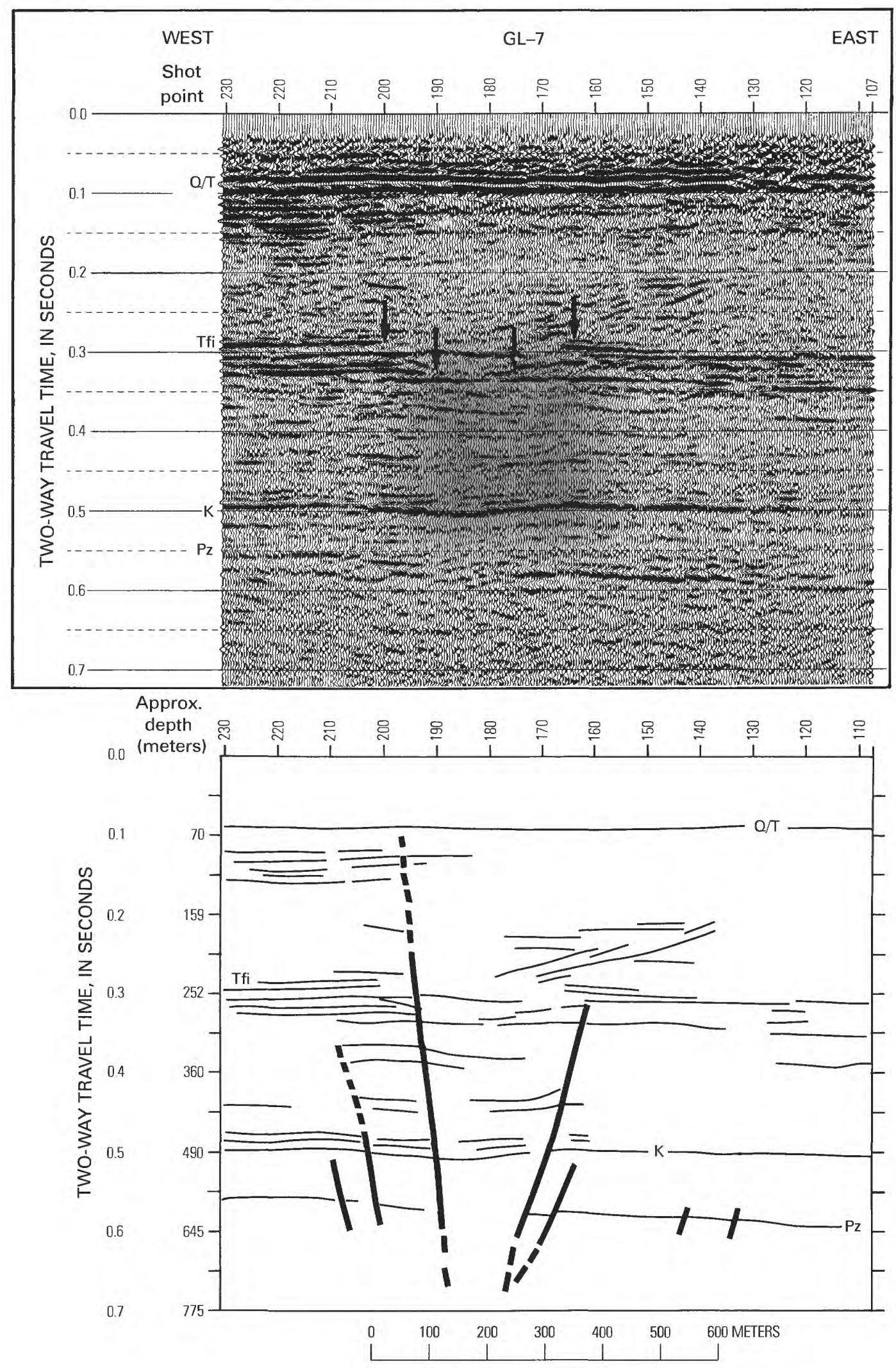

Figure 5. Migrated seismic reflection profile GL-7 and interpreted line drawing. Shot point 232 of line GL-7 is $528 \mathrm{~m}$ from shot point 300 of line GL-8. Labeled reflectors: Pz, top of Paleozoic rocks; $\mathrm{K}$, top of Cretaceous rocks; Tfi, top of Paleocene and Eocene Flour Island Formation; Q/T, Quaternary-Tertiary unconformity. 


\section{DATA ACQUISITION AND PROCESSING}

To examine the deformational style (fault distribution, displacement, and age) of Cenozoic strata across the northwestern rift margin, we acquired $8.5 \mathrm{~km}$ (six profiles, fig. 2) of high-resolution, shallow-reflection data using the Mini-Sosie acquisition method. The Mini-Sosie method typically uses three portable, hand-operated, nondestructive earth tampers as a source of random pulse energy. Sensors mounted on the foot pads of each earth tamper transmit, by way of backpack-mounted radio transmitters, the exact impact time to a recording truck. For a single shot point, impact time signals and return data are stored in temporary memory. The seismic record, written to tape for a specific shot point, is produced by a cross-correlation process. This process time-shifts the return data sample associated with an impact to the equivalent sample time of the initial impact, then sums the samples (Barbier, 1983; Wiles, 1979). By summing as many as 2,000 seismic records, obtained over a several-minute (2-4) time period, the Mini-Sosie method effectively reduces the effects of cultural-noise sources (Stephenson and others, 1992).

The field operations used in this study are similar to those outlined by Wiles (1979), and table 1 lists the data-acquisition parameters used. The surveys were conducted on dirt roads or along the dirt shoulders of paved roads and were designed to image reflectors between 50 and $800 \mathrm{~m}$ deep. Elevation corrections for datum-statics corrections were surveyed to $\pm 5 \mathrm{~cm}$. The field data were processed with a standard sequence of processing steps (Yilmaz, 1987) including post-stack migration. The resulting profiles consist of $0.7 \mathrm{~s}$ of two-way travel-time (TWTT) data that image about the upper $750 \mathrm{~m}$ of the Earth's crust.

\section{INTERPRETATION}

Physical-property changes due to formation lithologies, lateral facies continuity, and complexity of the depositional environment all affected the quality and continuity of reflector data. In general, coherent reflectors are resolvable from about 0.08 to $0.65 \mathrm{~s}$ (depths from about 50 to $700 \mathrm{~m}$ ) on all six profiles. Estimated depths are shown on the left side of each interpreted line drawing (figs. 4-8), but actual depths across each section may vary slightly due to velocity variations within changing lithologies.

The "Pz" reflector is interpreted to represent the unconformable contact between the eroded lower Paleozoic carbonate rocks and the Upper Cretaceous McNairy Sand. The " $\mathrm{K}$ " reflector is believed to represent the unconformable contact between the Upper Cretaceous McNairy Sand (including the Owl Creek Formation, if present) and the Tertiary Midway Group (fig. 3). The "Tfi" reflector is interpreted to represent the top of the Paleocene-Eocene Flour Island Formation, which is recognized as the top of the Wilcox Group (fig. 3). We interpret the reflector labeled "Q/T" to represent the unconformable contact between the eroded surface of middle Eocene Claiborne Group (possibly including the Jackson Group) and Quaternary strata.

Fault locations, discussed in the following text, are referenced to the shot point beneath which the fault trace crosses the Pz reflector. Within the study area, the largest amount of vertical deformation (warping or fault offset) is approximately $30 \mathrm{~m}$ and, in many cases, is less than $10 \mathrm{~m}$. For this study, we have chosen to identify, on the line drawings that accompany the reflection profiles, only those faults that show a clear disruption and (or) offset of the $\mathrm{Pz}$ reflector or those that are observed to extend above the $\mathrm{K}$ reflector. We use the term "prominent fault" to refer to faults that we interpret as extending near or above the Tfi reflector.

\section{PROFILE GL-8}

The only structural deformation interpreted on this profile (fig. 4) is minor warping of the Paleozoic ( $\mathrm{Pz}$ ) through Flour Island (Tfi) reflectors between shot points 320 and 360 . These reflectors are slightly deeper south of the warp, which accounts for the few milliseconds of southward dip seen across the profile. Uneven and subparallel intermittent reflection patterns between the $\mathrm{Tfi}$ and $\mathrm{Q} / \mathrm{T}$ reflectors are essentially horizontal and typical of imaged fluvial and deltaic depositional environments (Mitchum and others, 1977a, 1977b).

\section{PROFILE GL-7}

On profile GL-7 (fig. 5), the Pz reflection shows a net drop of approximately $25 \mathrm{~ms}$ (approximately $39 \mathrm{~m}$ ) across the 1.2-km profile. The majority of this $\mathrm{Pz}$ reflector drop occurs across a zone of poor reflector coherency (shot points 174-188) and a downwarped section (shot points 107-132) on the east end of the profile. We interpret the zone of poor reflector coherency to be a zone of highly fractured Paleozoic rock between a pair of prominent faults. Although the overall east-end-down drop of the Upper Cretaceous reflector $\mathrm{K}$ is approximately $7 \mathrm{~ms}$ (approximately $11 \mathrm{~m}$ ) across the profile, this reflector is downwarped and faulted by as much as $12 \mathrm{~ms}$ (approximately $18 \mathrm{~m}$ ) between the aforementioned faults (fig. 5). The Midway and Wilcox Group reflectors both show varying amounts of concave warping between the faults. The $\mathrm{Pz}, \mathrm{K}$, and multiple reflections associated with the Fort Pillow Sand and topped by the Tfi reflector are predominantly horizontal west of shot point 188 . All of the mentioned reflectors show a gentle down-to-the-east dip east 

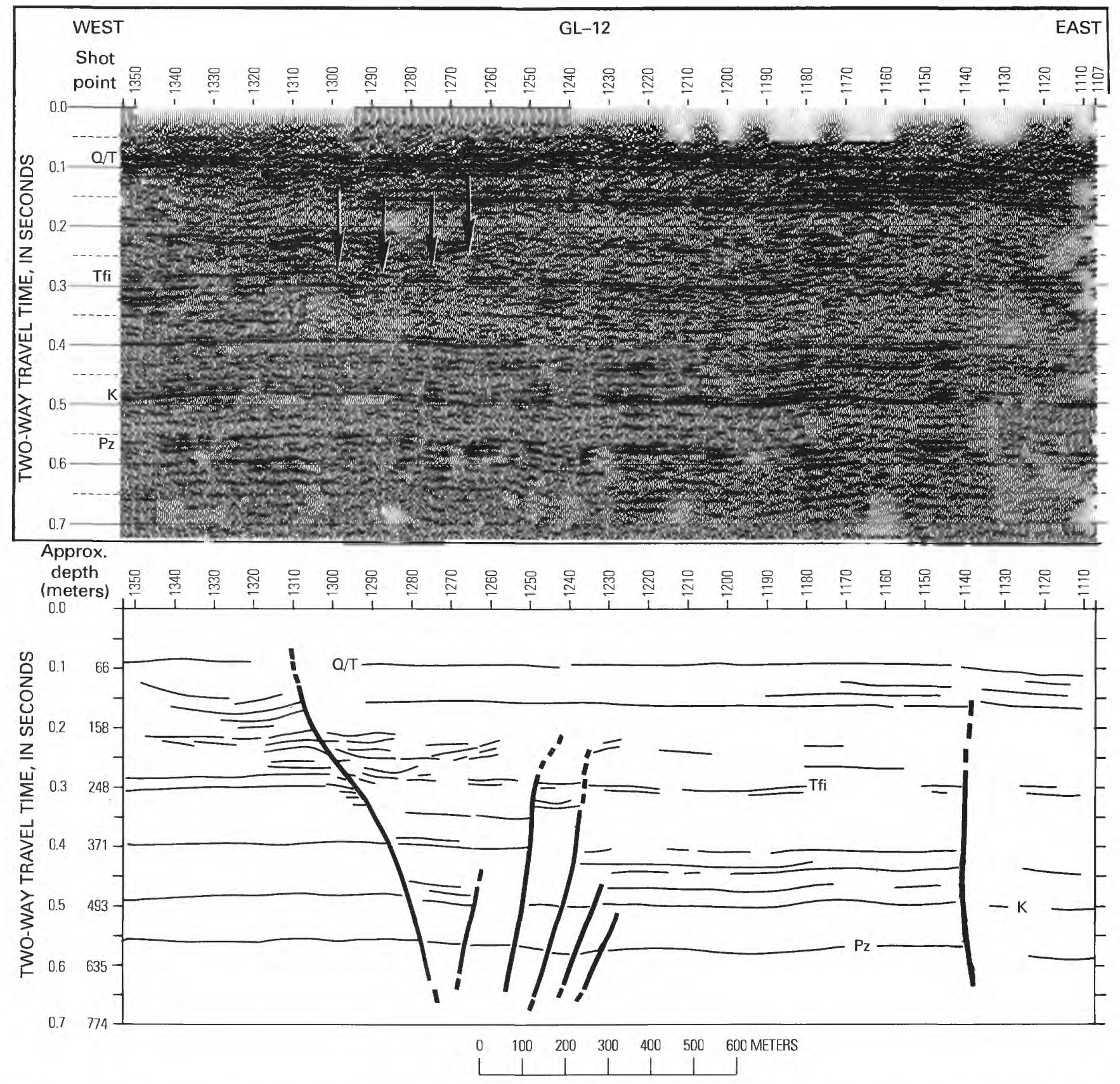

Figure 6. Migrated seismic reflection profile GL-12 and interpreted line drawing. Shot point 1096 of GL-12 is $310 \mathrm{~m}$ west of the railroad tracks passing through the town of Conran, Mo. Labeled reflectors: Pz, top of Paleozoic rocks; K, top of Cretaceous rocks; Tfi, top of Paleocene and Eocene Flour Island Formation; Q/T, Quaternary-Tertiary unconformity.

of the fault at shot point 174. Few of the other interpreted faults extend above the $\mathrm{K}$ reflector.

Between shot points 168 and 200, the zone coinciding with the prominent faults, reflections reveal a feature (arrows on fig. 5 profile) that we interpret to be an asymmetrical entrenched stream channel scoured into the Flour Island Formation. Sexton and others (1992) have interpreted several paleochannel features on Mini-Sosie-method profiles located both north and south of the study area. Their paleochannels are similar to the entrenched channel interpreted on profile GL-7 (fig. 5) in that they have similar characteristics and occur at approximately the same depth. To the right of the entrenched channel feature on profile GL-7 are drape and onlap signature patterns often associated with channel-fill and point-bar deposits (Mitchum, 1977a, 1977b). Above 200 $\mathrm{ms}$, reflectors are predominantly horizontal and show only a few milliseconds of down-to-the-east dip. Based on changes in the reflection character of the upper Claiborne Group and disruption and (or) truncation of nearly 
horizontal reflections between 100 and $150 \mathrm{~ms}$ TWTT, we interpret that the westernmost fault (of the entrenched channel bracketing faults) can be traced to approximately the $\mathrm{Q} / \mathrm{T}$ reflector. The east side prominent fault trace, shot point 174 , is not discernible above the top of the Wilcox Group. It is possible that this fault was active during deposition of the Memphis Sand; however, evidence for such activity has been obliterated by channel cut-and-fill processes.

\section{PROFILE GL-12}

On profile GL-12 (fig. 6), Pz and $\mathrm{K}$ reflectors show an overall drop of 26 and $23 \mathrm{~ms}$ (approximately 34 and $30 \mathrm{~m}$ ), respectively, from west to east. The majority of vertical displacement on the $\mathrm{Pz}$ reflector occurs along the prominent fault at shot point 1277 . Differing Memphis Sand and upper Claiborne Group reflection characteristics, along with a disrupted zone in the $\mathrm{Q} / \mathrm{T}$ reflector (near shot point 1310), allow this fault to be traced to within approximately $60 \mathrm{~m}$ of the surface. A highly fractured zone of closely spaced faults between shot points 1225 and 1265 disrupt and offset the $\mathrm{Pz}$ reflector. Two of the faults are traceable to at least the top of Flour Island strata. Between one of the aforementioned faults (shot point 1250) and the prominent fault at shot point 1277 , the $\mathrm{Pz}$ through Tfi reflectors show minor amounts of offset (generally less than $10 \mathrm{~m}$ ) and concave warping. Additionally, between these prominent faults we interpret an entrenched channel feature (arrows, fig. 6). This channel feature is similar to the one imaged on profile GL-7 in that a portion of the upper Wilcox Group (Fort Pillow Sand and Flour Island Formation) strata has been eroded. Other faults, offsetting and deforming Paleozoic to Midway Group reflectors, are present between and adjacent to the two prominent faults. Paleozoic through Wilcox Group reflectors are warped into an anticline between shot points 1160 and 1190. The eastern side of the anticline is bounded by a fault similar in appearance to the other prominent faults.

Upper Claiborne and $\mathrm{Q} / \mathrm{T}$ reflectors $(50-100 \mathrm{~ms}$ TWTT) are generally continuous and essentially horizontal across much of the profile. Tilting of upper Claiborne Group and younger strata eastward from shot point 1145 may indicate a component of normal and (or) oblique-slip movement on the fault at shot point 1140 during the Quaternary.

\section{PROFILE GL-9}

On GL-9 (fig. 7), the overall Pz reflector drop from north to south across the profile is approximately $10 \mathrm{~ms}$. An anticlinal warp of approximately $20 \mathrm{~ms}(26 \mathrm{~m})$, in the vicinity of the prominent fault at shot point 520 , represents the largest amount of deformation observable on this profile. Minor disruption and offset of the $\mathrm{Pz}$ reflector and minor concave warping, less than $10 \mathrm{~ms}$ (approximately 12 $\mathrm{m}$ ), of the K reflector are interpreted between faults at shot points 554 and 615 . Changes of reflection characteristics within the Claiborne Group and disruptions of strong, continuous reflections between 100 and $150 \mathrm{~ms}$ indicate that the northern fault trace (shot point 554) extends up to approximately the $\mathrm{Q} / \mathrm{T}$ reflector. Based on disruptions within the Wilcox Group reflector package and changes in scattered Claiborne Group reflectors, we extend the fault at shot point 615 into upper Claiborne Group strata. Although not as clearly imaged as on profiles GL-7 and GL-12 (figs. 5 and 6), there is evidence of stream-channel entrenchment of the upper Wilcox Group strata between the faults at shot points 554 and 580. Draping and onlapping reflection patterns are also identifiable within the fault-bounded area.

\section{PROFILES GL-10 AND GL-11}

Paleozoic, Upper Cretaceous, and Midway and Wilcox Group reflectors show a gentle west-to-east upwarping across profile GL-11 and the western edge of profile GL-10 (fig. 8). This gentle warping is disrupted by four prominent faults on profile GL-10. Approximately $30 \mathrm{~m}$ and $19 \mathrm{~m}$ of vertical offset (down to the east) on the $\mathrm{Pz}$ and $\mathrm{K}$ reflectors, respectively, are interpreted across a fault at shot point 820 . This fault, clearly imaged as a sharp break across the $\mathrm{Pz}$ and $\mathrm{K}$ reflectors, represents the east-side terminus of the upwarped area. A fault showing similar displacement characteristics (20 ms of normal displacement across the $\mathrm{Pz}$ and $\mathrm{K}$ reflectors, post-middle Eocene movement, and believed to have a northerly to northeasterly strike) is interpreted by Hamilton and Zoback (1982) to be approximately $1 \mathrm{~km}$ east of GL-10 on the USGS S-3 Vibroseis profile. Disruption and reduced $\mathrm{Pz}$ and $\mathrm{K}$ reflector coherency, along with concave warping of $\mathrm{K}$ through $\mathrm{Tfi}$ reflectors, is evident between the faults at shot points 765 and 792 (fig. 8). Another prominent fault is interpreted at shot point 735 . The faults at shot points 765 and 735 are traceable to 100 $\mathrm{ms}$ depth, where they are coincident with subtle $\mathrm{Q} / \mathrm{T}$ reflector disruption and tilting.

On profile GL-11, prominent faults are interpreted at shot points 965 and 978 . Both faults are traceable to the near-surface where the $\mathrm{Q} / \mathrm{T}$ reflector and shallow reflections above $100 \mathrm{~ms}$ show subtle changes in pattern characteristics (undulations and lack of lateral continuity) as well as a slight down-to-the-east tilt between shot points 935 and 975 (fig. 8). Little to no vertical displacement across the $\mathrm{Pz}$ and $\mathrm{K}$ reflectors is observed along these faults. 

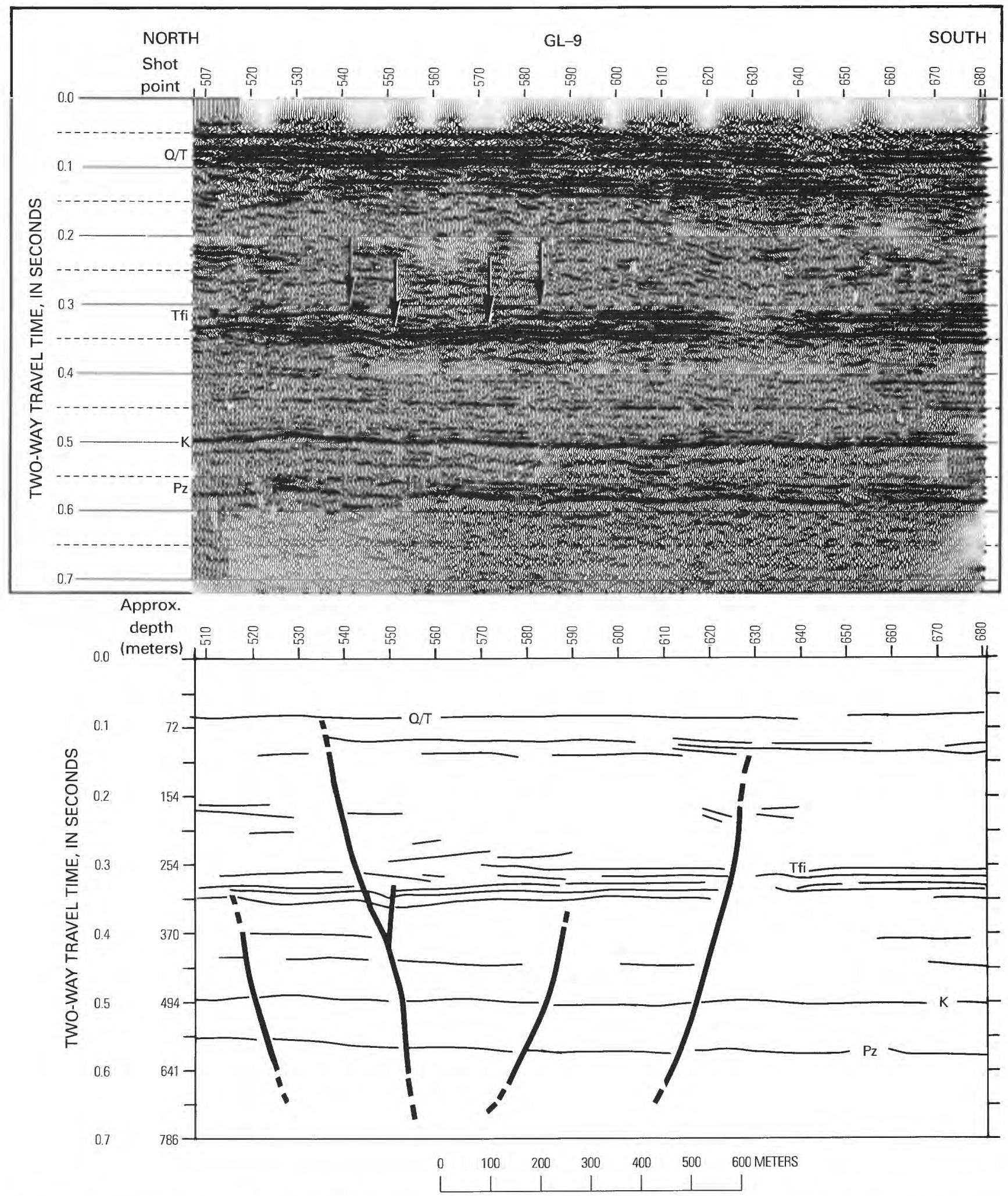

Figure 7. Migrated seismic reflection profile GL-9 and interpreted line drawing. Shot point 500 of profile GL-9, figure 8, is approximately $385 \mathrm{~m}$ south of shot point 232 of GL-7. Labeled reflectors: Pz, top of Paleozoic rocks; K, top of Cretaceous rocks; Tfi, top of Paleocene and Eocene Flour Island Formation; Q/T, Quaternary-Tertiary unconformity. 

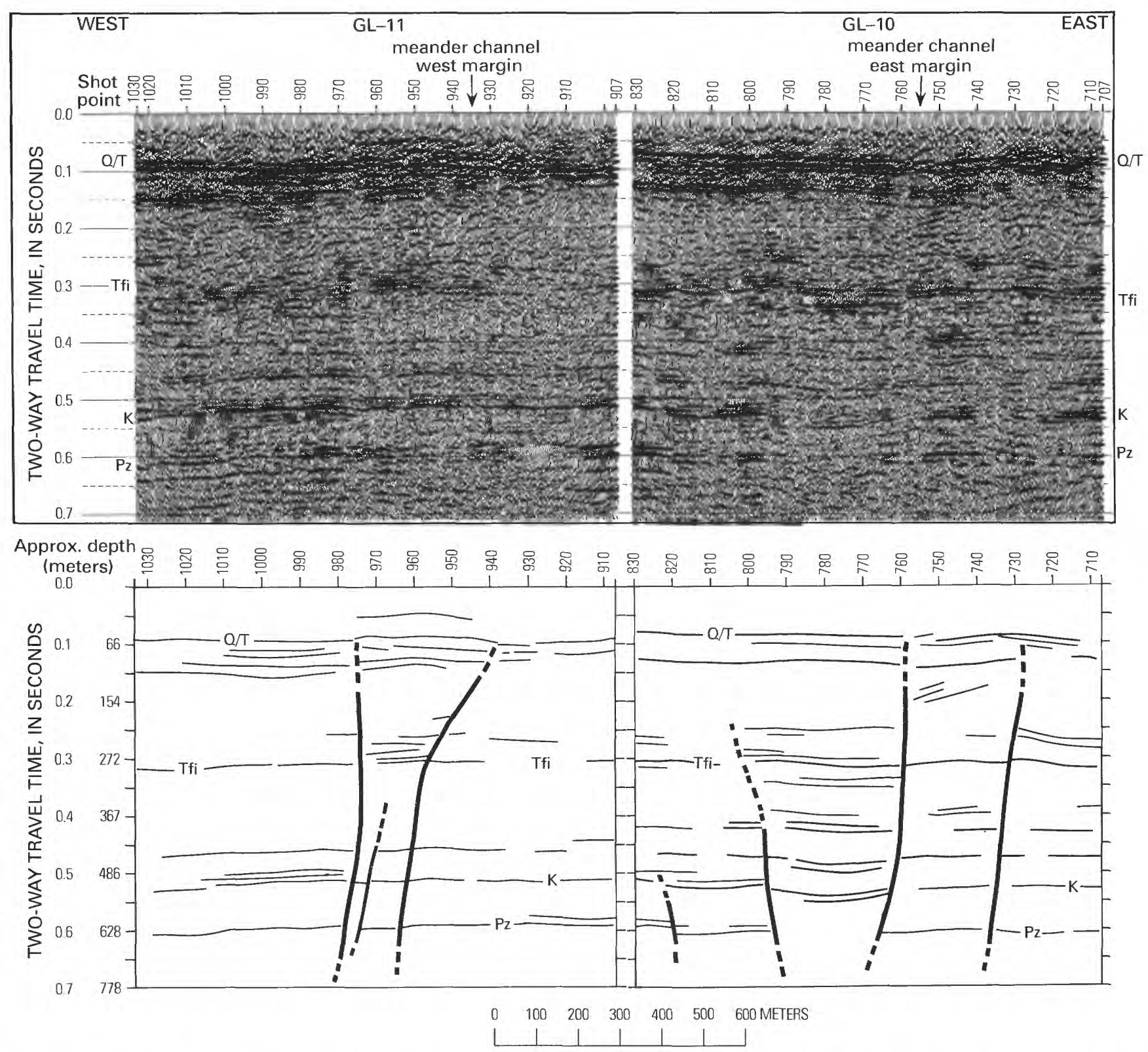

Figure 8. Migrated seismic reflection profiles and interpreted line drawing for lines GL-10 and GL-11. The distance between shot point 1035 , on the west end of GL-11, and the east end of GL-12 (fig. 7, shot point 1105 ) is $2,428 \mathrm{~m}$. Shot point 900 of profile GL-11 is $46 \mathrm{~m}$ west of shot point 840 on GL-10. Labeled reflectors: Pz, top of Paleozoic rocks; K, top of Cretaceous rocks; Tfi, top of Paleocene and Eocene Flour Island Formation; Q/T, Quaternary-Tertiary unconformity.

\section{DISCUSSION AND CONCLUSIONS}

The Mini-Sosie high-resolution seismic reflection data image several strong and regionally coherent reflectors within the Marston, Mo., study area. The Pz reflector, which we interpret to represent the eroded, low-relief surface at the top of the Paleozoic, slopes from approximately $550 \mathrm{~ms}$ on the west side of profile GL-12 to approximately $600 \mathrm{~ms}$ on the east side of GL-10. Although this reflector is highly disrupted in places with numerous small (less than $10 \mathrm{~m}$ vertical offset) faults, only a few faults are interpreted to extend up to approximately the Q/T reflector. The largest amount of vertical displacement on any fault within the study area is approximately $30 \mathrm{~m}$. Vertical displacement consistently decreases upward, with most displacement occurring across the $\mathrm{Pz}$ and $\mathrm{K}$ reflectors. We suspect that the faulting style imaged on five of the six Marston, Mo., profiles represents the near-surface expression of flower structures associated 


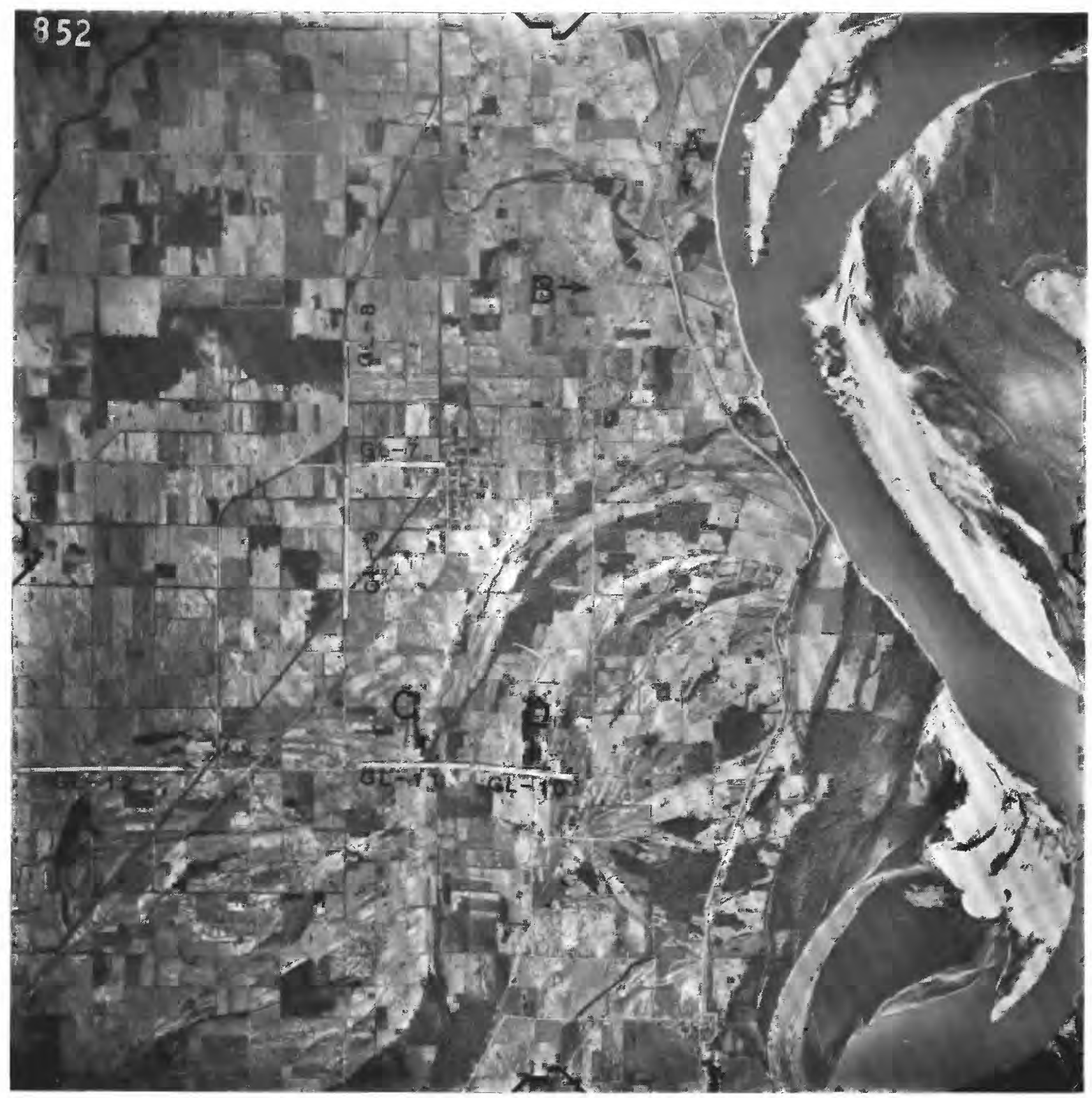

Figure 9. Vertical aerial photograph showing the spatial location of high-resolution seismic reflection lines (white) and three ages of abandoned meander channels associated with the modern Mississippi River. Arrow " $\mathrm{A}$ " marks northeast-trending stream segment. Arrow " $B$ " marks the northeast-trending surface lineation separating an area lacking sandblow features from an area of dense sandblow activity. Arrows " $C$ " and "D" mark positions where interpreted faults on profiles GL-10 and GL-11 (fig. 8) roughly coincide with features of recently abandoned channels.

with strike-slip and oblique movement of deeper, reactivated boundary faults. Earthquake-focal-mechanism studies have indicated that strike-slip faulting is dominant in the two northeast-trending zones of the NMSZ (Herrmann and Canas, 1978; Chiu and others, 1992). This study area is located within the intersection of one of the northeast arms and the north-northwest arm of seismicity (fig. 1). Flower-structure faulting of Paleozoic through Tertiary units (and possibly including Quaternary-age units) has also been identified northeast and southwest of Marston, Mo., by Sexton and others (1992) and Schweig and others (1992).

On three of six Mini-Sosie high-resolution seismic reflection profiles (GL-7, GL-9, and GL-12), we recognize a paired set of faults that have similar deformation characteristics. The interpreted fault pairs are as follows: profile GL-7, shot points 174 and 188; profile GL-9, shot 


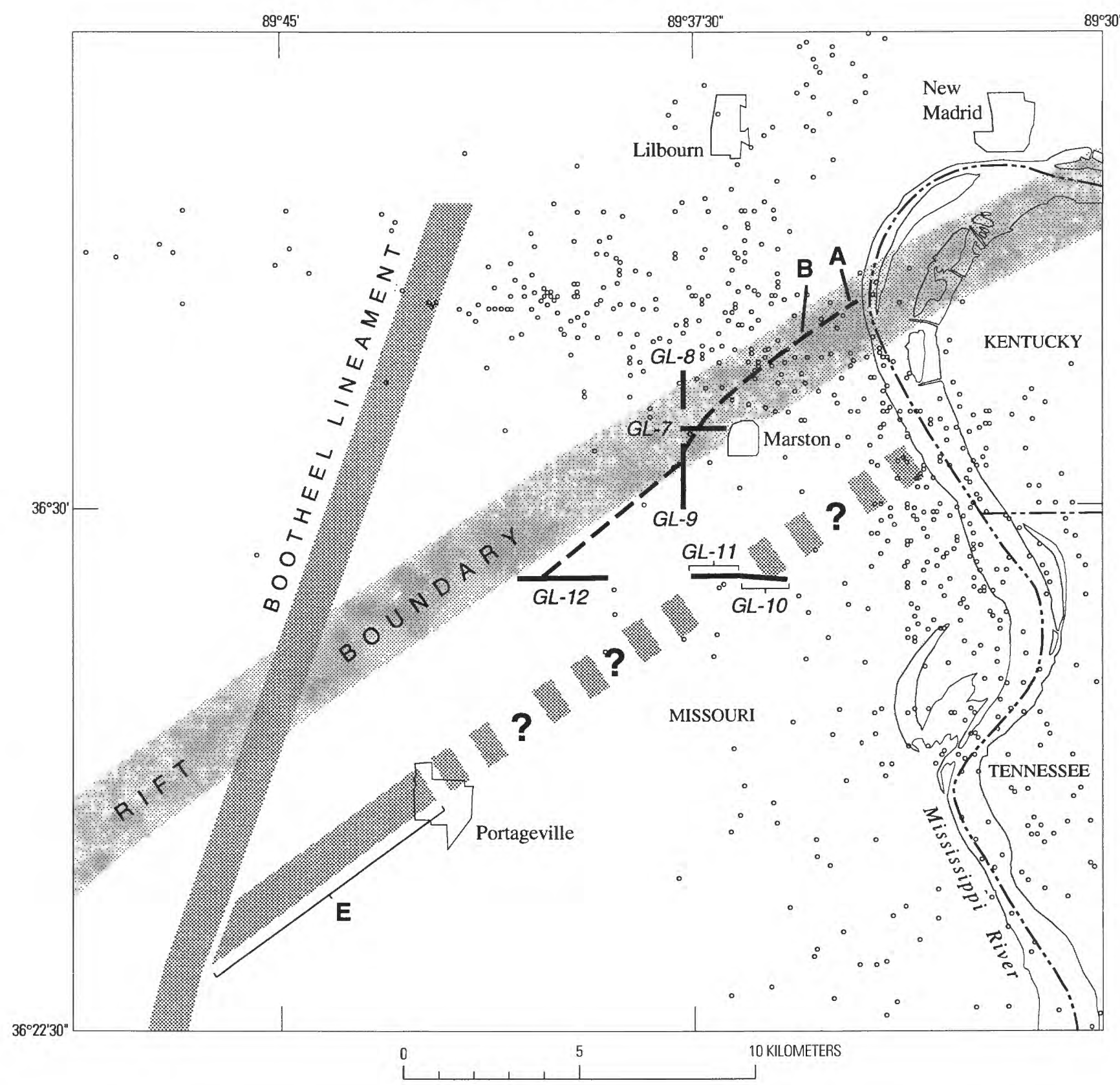

Figure 10. Conceptual map displaying the spatial relationship and trend (dashed line) of the structural feature interpreted from seismic profiles GL-7, GL-9, and GL-12, and surficial geomorphic features (A, B) observed on the aerial photograph shown in figure 9. Dark stippled pattern is the generalized trace of Bootheel lineament surficial features and a possible lineament splay (segment E) (Marple, 1989). Queried dark-stippled pattern represents the projected trend of a hypothetical northeast extension of the 5-km-long Bootheel lineament splay. Open circles indicate epicenters of earthquakes with $M \geq 1.5$ (Taylor and others, 1991).

points 554 and 578; and profile GL-12, shot points 1250 and 1277. For these fault pairs, the majority of vertical displacement across the $\mathrm{Pz}$ and $\mathrm{K}$ reflectors takes place along the westernmost fault (northernmost in the case of profile GL-9). From this relationship, we interpret that the westernmost fault of the pair is a master fault and the deeper fault is antithetic to it. All three fault pairs bracket downwarped Upper Cretaceous, Midway, and Wilcox Group reflectors and also show evidence of
Eocene-age stream-channel entrenchment. The imaged channel width, symmetry, and depth of entrenchment is approximately the same in all three cases. The north-south alignment of profile GL-9 is believed to cut the stream-channel feature at a more oblique angle than the other two profiles (GL-7 and GL-12), thus causing the difference in imaged channel configuration. It is our conclusion that profiles GL-7, GL-9, and GL-12 image a structural fault zone that can be projected across the 
seismic profile array for a distance of approximately $6 \mathrm{~km}$. In the vicinity of point " $A$ " (fig. 9), preliminary analysis of $50 \mathrm{~km}$ of high-resolution reflection data, collected on a Mississippi River transect, identifies the presence of normal and reverse faults that extend from the near-surface to the depth of resolution (Shedlock and others, 1988). Point "B" (fig. 9) identifies the position of a surface lineament that is on trend with the stream segment (point " $A$ "). The point " $B$ " lineament appears to mark a boundary between an area of white speckles (representing a fairly dense cluster of sandblow deposits) and a zone to the south that is somewhat devoid of sandblow deposits. These two features are on the projected trend of the fault zone interpreted from the seismic profile array. Figure 10, a plan-view map, shows the spatial distribution of the seismic lines and geomorphic features. As indicated on figure 10 , the $6-\mathrm{km}$-long fault zone interpreted from seismic reflection data possibly may be extended to a length of at least $15 \mathrm{~km}$, based on the geomorphic data.

The Bootheel lineament, first identified during the analysis of satellite images acquired by the SPOT (Systeme Probatoire $d /$ Obervation de la terre) multispectral scanner (MSS) and Landsat MSS systems and aerial photography, is traceable on the bases of surficial morphologic features from east of Marked Tree, Ark., to west of New Madrid, Mo., a distance of approximately $135 \mathrm{~km}$ (Marple and Schweig, 1992). Surface morphology and interpreted seismic reflection profiling indicate that the lineament is underlain by a complex zone of inferred multiple flower structures that have deformed the Quaternary/Tertiary $(\mathrm{Q} / \mathrm{T})$ reflector (Schweig and others, 1992). Schweig and Ellis (1992) suggest that surficial morphologic features of the Bootheel lineament may indicate that it is the surface expression of a very young strike-slip fault. Several other lineament features have been identified in the northern Mississippi Embayment (Marple, 1989; Marple and Schweig, 1992). Marple (1989) noted the presence of one such lineament (approximately $5 \mathrm{~km}$ long) about $5 \mathrm{~km}$ southeast of Marston, Mo., which he believed to be a splay to the Bootheel lineament. The $\mathrm{N} .50^{\circ}-55^{\circ} \mathrm{E}$. trend of this possible Bootheel lineament splay ("E" on fig. 10) is nearly parallel in orientation to the fault-zone feature (dashed line) portrayed on figure 10. A projected northeast extension of this splay (queried dark stipple pattern, fig. 10) would intersect profiles GL-10 and GL-11 in the vicinity of prominent fault traces that are interpreted to disrupt the $\mathrm{Q} / \mathrm{T}$ reflector. Points "C" and "D" (fig. 9), which roughly bracket the west and east margins of a young meander channel and the aforementioned prominent faults interpreted on profiles GL-10 and GL-11, are within the projected trend. Near " $\mathrm{C}$ ", the $\mathrm{Q} / \mathrm{T}$ and shallower reflectors show a small upwarp between two faults that intersect the $\mathrm{Q} / \mathrm{T}$ reflector at shot points 975 and 935 (fig. 8). East of shot point 935, the reflectors show a subtle down-to-the-east dip. Near "D", the $\mathrm{Q} / \mathrm{T}$ and shallower reflectors between the fault-trace projections at shot points 730 and 760 (fig. 8) show a subtle down-to-the-west dip, opposite to the down-to-the-east dip of similar Quaternary-age reflectors on GL-11. Hamilton and Zoback (1982) speculate that a fault identified on the USGS S-3 Vibroseis profile, just east of profile GL-10, has a north to northeasterly trend.

Based on imaged reflection characteristics and surficial morphologic features, we believe that a fault zone, trending approximately N. $50^{\circ}-55^{\circ}$ E., can be traced for a distance of at least $15 \mathrm{~km}$ across the Marston, Mo., study area. Within $2 \mathrm{~km}$ southeast of this fault zone, several prominent faults are imaged across profiles GL-10 and GL-11. Four of these faults are traceable to at least the $\mathrm{Q} / \mathrm{T}$ boundary and may disrupt younger strata as well. The potential seismic hazard that these features represent to the northern Mississippi Embayment is currently unclear due to the lack of understanding of the local relationship of these features to each other. A key element to understanding the local relationship is the determination of whether or not the Bootheel lineament splay, observed by Marple (1989), is a seismogenic feature. If this splay is a fault-related surface feature, it then becomes crucial to determine if there exists a link between it, the prominent faults imaged on profiles GL-10 and (or) GL-11, and faults identified by the Mississippi River seismic survey. If linkage is confirmed, it would indicate the presence of a several-kilometer-wide, northeast-trending fault zone with a known length of at least $25 \mathrm{~km}$.

\section{REFERENCES CITED}

Autin, W.F., Burns, S.F., Miller, B.J., Saucier, R.T., and Snead, J.I., 1991, Quaternary geology of the lower Mississippi Valley, in Morrison, R.B., ed., Quaternary Nonglacial Geology, Conterminous U.S.: Boulder, Colorado, Geological Society of America, The Geology of North America, v. K-2, p. 547-581.

Barbier, M.G., 1983, The Mini-Sosie method: Boston, Massachusetts, International Human Resources Development Corp., $86 \mathrm{p}$.

Bond, G.C., Nickeson, P.A., and Kominz, M.A., 1984, Breakup of a supercontinent between $625 \mathrm{Ma}$ and $555 \mathrm{Ma}$ - New evidence and implications for continental histories: Earth and Planetary Science Letters, v. 70, p. 325-345.

Boswell, E.H., Moore, G.K., MacCary, L.M., and others, 1965, Cretaceous aquifers in the Mississippi Embayment: U.S. Geological Survey Professional Paper 448-C, 37 p.

Chiu, J.M., Johnston, A.C., and Yang, Y.T., 1992, Imaging the active faults of the central New Madrid seismic zone using PANDA area data: Seismological Research Letters, v. 63, no. 3, p. 375-394.

Crone, A.J., 1981, Sample description and stratigraphic correlation of the New Madrid Test Well 1-X, New Madrid County, Missouri: U.S. Geological Survey Open-File Report 81-426, p. 26. 
Crone, A.J., and Brockman, S.R., 1982, Configuration and deformation of Paleozoic bedrock surface in the New Madrid seismic zone, chap. I of McKeown, F.A., and Pakiser, L.C., eds., Investigations of the New Madrid, Missouri, Earthquake Region: U.S. Geological Survey Professional Paper 1236, p. 115-135.

Cushing, E.M., Boswell, E.H., and Hosman, R.L., 1964, General geology of the Mississippi Embayment: U.S. Geological Survey Professional Paper 448-B, 28 p.

Dart, R.L, and Swolfs, H.S., 1991, Contemporary stress in northeastern Arkansas: Eos, American Geophysical Union Transactions, v. 72, no. 17 , p. 264.

Fisk, H.N., 1944, Geological investigation of the alluvial valley of the lower Mississippi River: Vicksburg, Mississippi River Commission, $78 \mathrm{p}$.

Grohskopf, J.G., 1955, Subsurface geology of the Mississippi Embayment of southeast Missouri: Missouri Geological Survey and Water Resources Bulletin 37, no. 5, 133 p.

Guccione, M.J., Prior, W.L., and Rutledge, E.M., 1990, The Tertiary and early Quaternary geology of Crowley's Ridge, in Guccione, M.J., and Rutledge, E.M., eds., Field Guide to the Mississippi Alluvial Valley, Northeast Arkansas and Southeast Missouri: Friends of the Pleistocene, South-Central Cell, p. $23-44$.

Hamilton, R.M., and McKeown, F.A., 1988, Structure of the Blytheville arch in the New Madrid seismic zone: Seismological Research Letters, v. 59, no. 4, p. 117-121.

Hamilton, R.M., and Zoback, M.D., 1982, Tectonic features of the New Madrid seismic zone from seismic-reflection profiles, chap. F of McKeown, F.A., and Pakiser, L.C., eds., Investigations of the New Madrid, Missouri, Earthquake Region: U.S. Geological Survey Professional Paper 1236, p. 55-82.

Herrmann, R.B., and Canas, J.A., 1978, Focal mechanism studies in the New Madrid seismic zone: Bulletin of Seismological Society of America, v. 68, p. 1095-1102.

Hildenbrand, T.G., 1985, Rift structure of northern Mississippi Embayment from the analysis of gravity and magnetic data: Journal of Geophysical Research, v. 90, no. 13, p. 12607-12622.

Hildenbrand, T.G., and Hendricks, J.D., 1995, Geophysical setting of the Reelfoot rift and relations between rift structures and the New Madrid seismic zone, chap. E of Shedlock, K., and Johnston, A., eds., Investigations of the New Madrid seismic zone: U.S. Geological Survey Professional Paper 1538.

Hildenbrand, T.G., Kane, M.F., and Stauder, William, 1977, Magnetic and gravity anomalies in the northern Mississippi Embayment and their spatial relation to seismicity: U.S. Geological Survey Miscellaneous Field Studies Map MF-914, scale $1: 1,000,000$

Howe, J.R., and Thompson, T.L., 1984, Tectonics, sedimentation, and hydrocarbon potential of the Reelfoot rift: Oil and Gas Journal, Nov. 12, p. 174-190.

Johnston, A.C., in press, The stable continental region earthquake data base: Palo Alto, California, Electric Power Research Institute, EPRI Report RP-2556-12.

Johnston, A.C., and Kanter, L.R., 1990, Earthquakes in stable continental crust: Scientific American, v. 262, no. 3, p. 68-75.

Johnston, A.C., and Nava, S.J., 1990, Seismic-hazard assessment in the Central United States, in Krinitzsky, E.L., and Slemmons, D.B., eds., Neotectonics in Earthquake Evaluation: Boulder,
Colorado, Geological Society of America Reviews in Engineering Geology, v. 8, p. 47-58.

Kane, M.F., Hildenbrand, T.G., and Hendricks, J.D., 1981, Model for the tectonic evolution of the Mississippi Embayment and its contemporary seismicity: Geology, v. 9, p. 563-568.

Kolata, D.R., and Nelson, W.J., 1991, Basin-forming mechanisms of the Illinois Basin, chap. 19 of Leighton, M.W., Kolata, D.R., Oltz, D.F., and Eidel, J.J., eds., Interior Cratonic Basins: American Association of Petroleum Geologists Memoir 51, p. 287-291.

Luzietti, E.A., and Harding, S.T., 1991, Reconnaissance seismic-reflection surveys in the New Madrid seismic zone, northeast Arkansas and southeast Missouri: U.S. Geological Survey Miscellaneous Field Studies Map MF-2135.

Luzietti, E.A., Kanter, L.R., Schweig, E.S., Shedlock, K.M., and VanArsdale, R.B, 1992, Shallow deformation along the Crittenden County fault zone near the southeast margin of the Reelfoot rift, northeast Arkansas: Seismological Research Letters, v. 63 , no. 3 , p. $263-276$.

Mann, C.J., and Thomas, W.A., 1968, The ancient Mississippi River: New Orleans, Louisiana, Gulf Coast Association of Geological Societies Transactions, v. 18, p. 187-204.

Marcher, M.V., and Stearns, R.G., 1962, Tuscaloosa Formation in Tennessee: Geological Society of America Bulletin, v. 73, p. 1365-1386.

Marple, R.T., 1989, Recent discoveries in the New Madrid seismic zone using remote sensing: Memphis, Tennessee, Memphis State University, M.S. thesis, 81 p.

Marple, R.T., and Schweig, E.S. III, 1992, Remote sensing of alluvial terrain in a humid, tectonically active setting--The New Madrid seismic zone: Photogrammetric Engineering and Remote Sensing, v. 58, no. 2, p. 209-219.

Mitchum, R.M., Vail, P.R., Jr., and Sangree, J.B., 1977a, Seismic stratigraphy and global changes of sea level; Part 6, Seismic interpretation of seismic reflection patterns in depositional sequences, in Payton, C.E., ed., Seismic Stratigraphy-Applications to Hydrocarbon Exploration: American Association of Petroleum Geologists Memoir 26, p. 117-133.

Mitchum, R.M., Vail, P.R., Jr., and Thompson, S., III, 1977b, Seismic stratigraphy and global changes of sea level; Part 2, The depositional sequence as a basic unit for stratigraphic analysis, in Payton, C.E., ed., Seismic Stratigraphy-Applications to Hydrocarbon Exploration: American Association of Petroleum Geologists Memoir 26, p. 53-62.

Potter, P.E., 1955, The petrology and origin of the Lafayette Gravel-Part 2, Geomorphic history: Journal of Geology, v. 63 , no. 2, p. 115-132.

Pryor, W.A., 1960, Cretaceous sedimentation in upper Mississippi Embayment: American Association of Petroleum Geologists Bulletin, v. 44, no. 9, p. 1473-1504.

Royall, P.D., Delcourt, P.A., and Delcourt, H.R., 1991, Late Quaternary paleoecology and paleoenvironments of the central Mississippi alluvial valley: Geological Society of American Bulletin, v. 103, p. 157-170.

Russ, D.P., 1982, Style and significance of surface deformation in the vicinity of New Madrid, Missouri, chap. H of McKeown, F.A., and Pakiser, L.C., eds., Investigations of the New Madrid, Missouri, Earthquake Region: U.S. Geological Survey Professional Paper 1236, p. 95-114. 
Russell, E.E., and Parks, W.S., 1975, Stratigraphy of the outcropping upper Cretaceous, Paleocene, and lower Eocene in western Tennessee (including descriptions of younger fluvial deposits): Tennessee Division of Geology Bulletin 75, $118 \mathrm{p}$.

Saucier, R.T., 1964, Geological investigation of the St. Francis basin, lower Mississippi Valley: Vicksburg, Mississippi, U.S. Army Corps of Engineers, Waterways Experiment Station, Technical Report 3-659.

Schweig, E.S., III, and Ellis, M.A., 1992, Distributed faulting along the Bootheel lineament-Smoothing over the rough spots in the New Madrid seismic zone [abs.]: Seismological Research Letters, v. 63, p. 50.

Schweig, E.S. III, Shen, F., Kanter, L.R., Luzietti, E.A., VanArsdale, R.B., Shedlock, K.M., and King, K.W., 1992, Shallow seismic reflection survey of the Bootheel lineament area, southeastern Missouri: Seismological Research Letters v. 63, no. 3, p. 285-295.

Sexton, J.L., Frey, E.P., and Malicki, Dave, 1982, High-resolution seismic-reflection surveying on Reelfoot scarp, northwestern Tennessee, chap. J of McKeown, F.A., and Pakiser, L.C., eds., Investigations of the New Madrid, Missouri, Earthquake Region: U.S. Geological Survey Professional Paper 1236, p. 137-149.

Sexton, J.L., Henson, H., Dial, P., and Shedlock, K.M., 1992, Mini-Sosie high-resolution seismic-reflection profiles along the Bootheel lineament in the New Madrid seismic zone: Seismological Research Letters, v. 63, no. 3, p. 297-307.

Sexton, J.L., and Jones, P.B., 1986, Evidence for recurrent faulting in the New Madrid seismic zone from Mini-Sosie high-resolution reflection data: Geophysics, v. 51, no. 9, p. 1760-1788.

1988, Mini-Sosie high-resolution survey of the Cottonwood Grove fault in northwestern Tennessee: Seismological Society of America Bulletin, v. 78, no. 2, p. 838-854.

Shedlock, K.M., and Harding, S.T., 1982, Mississippi River survey: Geophysical Research Letters, v. 9, p. 1275-1278.

Shedlock, K.M., Harding, S.T., and Luzietti, E.A., 1988, Near-surface faulting under the Mississippi River near New Madrid, Missouri [abs.]: Eos, American Geophysical Union Transactions, v. 69 , no. 44 , p. 1314.
Stauder, W., Kramer, M., Fischer, G., Schaeffer, S., and Morrissey, S.T., 1976, Seismic characteristics of southeast Missouri as indicated by a regional telemetered microearthquake array: Seismological Society of America Bulletin, v. 66, no. 6, p. 1953-1964.

Stearns, R.G., 1957, Cretaceous, Paleocene, and lower Eocene geologic history of the northern Mississippi Embayment: Geological Society of America Bulletin, v. 68, p. 1077-1100.

Stephenson, L.W., and Crider, A.F., 1916, Geology and ground waters of northeastern Arkansas, with a discussion of The chemical character of the waters, by R.B. Dole: U.S. Geological Survey Water-Supply Paper 399, 315 p.

Stephenson, W.J., Odum, J.K., Shedlock, K.M., Pratt, T.L., and Williams, R.A., 1992, Mini-Sosie high-resolution seismic method aids hazard studies: Eos, American Geophysical Union Transactions, v. 73, no. 44, p. 473-476.

Taylor, K., Stauder, W., and Herrmann, R., 1991, A comprehensive, unified data set for the New Madrid seismic array [abs.]: Seismological Research Letters, v. 62, p. 187.

Teller, J.T., 1990, Volume and routing of late-glacial runoff from the southern Laurentide ice sheet: Quaternary Research, v. 34, p. 12-23.

VanArsdale, R.B., Schweig, E.S. III, Kanter, L.R., Williams, R.A., Shedlock, K.M., and King, K.W., 1992, Preliminary shallow seismic-reflection survey of Crowley's Ridge, northeast Arkansas: Seismological Research Letters, v. 63, no. 3, p. 309-319.

Wiles, C.J., 1979, Mini-Sosie-New concept in high-resolution seismic surveys: Oil and Gas Journal, v. 77, March 12, p. 94-97.

Yilmaz, O., 1987, Seismic data processing, in the collection Investigations in Geophysics: Tulsa, Oklahoma, Society of Exploration Geophysics, $526 \mathrm{p}$.

Zoback, M.L., and Zoback, M.D., 1981, State of stress and intraplate earthquakes in the United States: Science, v. 213, p. 96-104.

1989, Tectonic stress field of the continental United States: Geological Society of America Memoir 172, p. 523-539.

Published in the Central Region, Denver, Colorado

Manuscript approved for publication November 2, 1994

Edited by Richard W. Scott, Jr.

Photocomposition and graphics preparation by Norma J. Maes; extensive use has been made of author-drafted material 

